\title{
Interleukin-2 Receptor
}

National Cancer Institute

\section{Source}

National Cancer Institute. Interleukin-2 Receptor. NCI Thesaurus. Code C104679.

A heterotrimeric protein found on the cell surface of immune cells that binds to interleukin-2. This receptor is comprised of alpha, beta and gamma subunits; the alpha and beta subunits bind interleukin-2 while the downstream ligand-dependent signaling is mediated by the gamma subunit. 